\title{
Fermentation Acids, Aerobic Fungal Growth, and Intake of Napiergrass Ensiled with Nonfiber Carbohydrates
}

\author{
C.-M. J. Yang, ${ }^{1}$ S.-C. Huang, ${ }^{1}$ T. Chang, ${ }^{2}$ Y.-H. Cheng, ${ }^{1}$ and C.-T. Chang ${ }^{1}$ \\ ${ }^{1}$ Department of Animal Science, National I-Lan University, I-Lan, Taiwan 260 ROC \\ ${ }^{2}$ Department of Animal Science, National Ping-Tung University of Science and Technology, Ping-Tung, Taiwan 912 ROC
}

\begin{abstract}
This study evaluated fermentation characteristics and fungal numbers of napiergrass silages prepared with and without added raw or heated corn meal (10\%, freshweight basis) at ensiling. Corn was added to napiergrass so that the silage would contain concentrate similar to that of corn silage with minimum grain content. The silages treated with raw or heated corn were fed to dairy does to compare voluntary silage consumption. After 8 wk of fermentation, $\mathrm{pH}$ for silage treated with heated corn was lowest, and that for napiergrass ensiled alone was highest among the treatments. The addition of corn increased lactic acid, but propionic and butyric acids were also elevated. Acetic acid decreased in response to the supplementation of corn but remained the dominant acid for all silages. Numbers of fungi (yeasts plus molds) in silages did not differ significantly at silo opening or after $24 \mathrm{~h}$ of exposure to air. However, the numbers of fungi at $48 \mathrm{~h}$ in aerated silages containing corn were lower than were the fungi counts in the control silage. When the silages were offered free choice along with concentrate at a fixed rate, dairy does tended to consume more silage treated with heated corn than raw corn. Whole-tract nutrient digestibility and serum glucose and urea $\mathrm{N}$ were not altered. These results indicate that the addition of either raw or heated corn meal to napiergrass at ensiling was beneficial to silage fermentation quality because it decreased $\mathrm{pH}$, increased lactic acid, and apparently suppressed fungal populations via elevated antifungal acids. A further advantage of heated corn vs. raw corn was increased silage intake.
\end{abstract}

(Key words: napiergrass, raw corn, heated corn, silage)

Abbreviation key: ADL = acid detergent lignin, $\mathbf{B C}=$ buffering capacity, NFC = nonfiber carbohydrates, $\mathbf{W S C}=$ water-soluble carbohydrates.

\section{INTRODUCTION}

Napiergrass (Pennisetum purpureum) is a bunch-type, fast-growing forage that has been stored by ensiling and

Received July 14, 2003.

Accepted November 8, 2003.

Corresponding author: C.-M. J. Yang; e-mail: cmyang@niu.edu.tw. compared with corn silage for feeding dairy cows (Ruiz et al., 1992). To obtain a large quantity per harvest from relatively small fields, the tall napiergrass cultivar at a late stage of growth is often used for ensilage to feed dairy cows and goats in Taiwan. However, the silage usually does not produce acceptable fermentation characteristics and is susceptible to aerobic deterioration at the time of feeding, especially when the weather is hot and humid. Silages that have undergone aerobic deterioration can affect animal intake (Whitlock et al., 2000), and the disposal of spoiled silage presents potential pollution to the environment.

Similar to many other grasses grown in subtropics and tropics, poor quality from ensiling napiergrass could be associated with a limitation in fermentable carbohydrates, aside from high moisture content and buffering capacity (BC) (McDonald et al., 1991). Forages with high moisture content and BC may require additional carbohydrates to increase lactic acid and reduce $\mathrm{pH}$ during silage fermentation (Muck, 1988).

Adding water-soluble carbohydrate (WSC) sources, such as molasses (Yokota et al., 1991), glucose (Tamada et al., 1999), and cassava meal (Panditharatne et al., 1986) to fresh napiergrass at ensiling has resulted in increased lactic acid production. However, the effect on stability of aerated silages is uncertain. High lactic acid contents in other silages have been associated with fungal growth upon aerobic exposure (Umaña et al., 1991; Weinberg et al., 1993), and a more lactic-type of fermentation often accompanies reduced VFA production. These acids are potent against fungal growth (Woolford, 1975). Increasing readily fermentable carbohydrates to enhance rapid silage fermentation may not necessarily ensure stable silages during aeration.

Corn is rich in nonfiber carbohydrates (NFC) and is an alternative source to provide fermentable carbohydrates for silage fermentation. The carbohydrates in corn contain mainly starch rather than sugars and, presumably, are less readily soluble and available for lactic acid bacteria. Sibanda et al. (1997) added corn to tropical grass-based forage at ensiling and observed a reduction in silage $\mathrm{pH}$ with no change in lactic acid, but also observed elevated acetic and butyric acid content. The addi- 
Table 1. Chemical composition of fresh napiergrass and of raw and heated corn meal for ensilage.

\begin{tabular}{lccc}
\hline Item $^{1}$ & Napiergrass & Raw corn & Heated corn \\
\hline DM, \% & 16.9 & 88.2 & 90.3 \\
OM, \% of DM & 88.9 & 98.7 & 99.1 \\
CP, \% of DM & 9.18 & 9.26 & 9.19 \\
NDF, \% of DM & 60.2 & 9.48 & 8.79 \\
ADF, \% of DM & 35.7 & 3.05 & 3.31 \\
Ether extract, \% of DM & 5.25 & 4.68 & 3.93 \\
ADL, \% of DM & 4.18 & 1.21 & 1.03 \\
NFC, \% of DM & 14.3 & 75.3 & 77.2 \\
WSC, \% of DM & 8.56 & 1.38 & 2.21 \\
WSC/NFC, \% of NFC & 59.9 & 1.83 & 2.86 \\
BC, meq. \% of DM & 27.4 & 9.07 & 6.64 \\
WSC:BC & 0.312 & 0.152 & 0.333 \\
NFC:BC & 0.522 & 8.302 & 11.626 \\
\hline
\end{tabular}

${ }^{1} \mathrm{ADL}=$ acid detergent lignin, $\mathrm{NFC}=$ nonfiber carbohydrate $(\mathrm{OM}-\mathrm{CP}-$ ether extract $-\mathrm{NDF}), \mathrm{WSC}=$ water-soluble carbohydrates, and $\mathrm{BC}=$ buffering capacity.

tion of molasses decreased $\mathrm{pH}$ by simultaneously increasing lactic acid with decreasing VFA.

Limited research has been conducted to investigate the effect of adding corn to napiergrass or other forages on silage fermentation, aerobic stability, and feeding value for animals. If added corn could lead to a more heterolactic-type of silage fermentation, then the production of short-chain antifungal VFA along with lactic acid would benefit both silage fermentation quality and aerobic stability, and possibly animal intake. Goats are particularly selective against spoiled feeds.

Although only limited amounts of corn are grown in Taiwan, feed corn grain is imported and is commercially available in raw or heated form. Heat treatment of corn increases carbohydrate availability by disrupting the protein matrix surrounding starch granules and gelatinizes starch (Theurer et al., 1999). Therefore, supplementation of heated corn to ensilage may further enhance heterolactic fermentation and suppress fungal proliferation, especially during aeration. The objective of this study was to evaluate the effect of incorporating raw or heated corn meal into napiergrass prior to ensiling on silage fermentation characteristics and aerobic fungal growth. Silages treated with raw and heated corn were fed to dairy does to compare forage intake and nutrient digestibility.

\section{MATERIALS AND METHODS}

\section{Silage Fermentation}

Napiergrass at heading (approximately $2 \mathrm{~m}$ tall) was collected from a field at a cutting height of $10 \mathrm{~cm}$ from the ground. The forage was chopped without wilting and immediately ensiled alone or with $10 \%$ of raw or heated corn meal as a NFC source on a fresh-weight basis. Table 1 lists the composition of the napiergrass before ensiling and of the raw and heated corn. The corn meals were obtained commercially (Good Feed Industry Co. Ltd., Luchu, Kaohsiung, Taiwan, ROC). According to the manufacturer's specification, heat treatment of corn was prepared by subjecting the whole corn kernel to dry hot air at $170^{\circ} \mathrm{C}$ for $30 \mathrm{~s}$. Water was then added to corn to reduce the temperature and to adjust moisture content to about $11 \%$. The final step was to roll the corn before grinding. The composition of napiergrass resembles that of corn plants without ears (NRC, 1989), and corn silage DM contains approximately 40 to $50 \%$ grain (Church, 1991). The selected rate of adding corn to napiergrass was intended to produce silage similar to corn silage that contained minimal amounts of grain, about $35 \%$ of forage $\mathrm{DM}$ at ensiling, based on the DM contents of the separate feeds used.

Individual corn meals were added by sprinkling onto napiergrass and were mixed manually before ensiling. The forage mixture for each treatment was packed by hand into three 200-L capacity plastic drums. After filling, the drums were capped with lids and sealed with metal crimps. Silos were stored at ambient temperature in a barn for $8 \mathrm{wk}$. Representative samples from fresh original materials were taken before mixing and frozen $\left(-20^{\circ} \mathrm{C}\right)$ for subsequent analysis of chemical contents. At silo opening, samples from the center of each individual drum silo were collected with a core sampler for analysis. The drums were resealed immediately after sampling.

\section{Fungal Growth in Aerated Silages}

Changes in $\mathrm{DM}, \mathrm{pH}$, and fungal populations of silages during aeration were monitored. A portion (approximately $2 \mathrm{~kg}$ ) of fresh silage from each drum silo was placed in a 20-L bucket and exposed to air at ambient temperature in the laboratory. Aerated silages were mixed and sampled at 24 and $48 \mathrm{~h}$ of exposure, and DM, $\mathrm{pH}$, and fungal counts were determined. 
Table 2. Ingredient and nutrient composition (\% of DM) of ingested diets by dairy goats fed napiergrass ensiled with raw or heated corn meal.

\begin{tabular}{lll}
\hline Item & Raw corn & $\begin{array}{l}\text { Heated } \\
\text { corn }\end{array}$ \\
\hline $\begin{array}{l}\text { Ingredient } \\
\text { Silage }\end{array}$ & & \\
$\quad$ Concentrate & & 70.3 \\
Nutrient & 68.7 & 29.7 \\
OM & 31.3 & \\
CP & & 90.4 \\
NDF & 89.8 & 10.7 \\
ADF & 11.5 & 53.2 \\
NFC $^{2}$ & 49.1 & 28.7 \\
\hline
\end{tabular}

${ }^{1}$ Consisted of $50.0 \%$ ground corn, $17.7 \%$ soybean meal, $14.7 \%$ wheat bran, $16.2 \%$ alfalfa meal, $0.40 \%$ limestone, $0.40 \%$ dicalcium phosphate, $0.20 \%$ salt, $0.20 \%$ trace mineral salt, and $0.20 \%$ vitamin premix.

${ }^{2} \mathrm{NFC}=$ nonfiber carbohydrate $(\mathrm{OM}-\mathrm{CP}-$ ether extract-NDF $)$.

\section{Forage Intake and Digestion Experiment}

Eight non-lactating crossbred (Sannan $\times$ Toggenburg $\times$ Nubian) dairy does ( $18.7 \pm 1.6 \mathrm{~kg}$ of BW, approximately 4 mo of age) were assigned randomly to be fed napiergrass silages treated with raw corn or heated corn. Goats were placed in individual stainless metabolism crates $(1.2 \mathrm{~m} \times 0.56 \mathrm{~m})$ designed to allow determination of feed intake and collection of feces in pens with mesh floor. The weighed fresh silage was provided twice daily in two equal portions at 0800 and $1800 \mathrm{~h}$ to allow $10 \%$ weigh back. Orts, mainly stems, were weighed to determine voluntary DMI. A commercial concentrate mix $(90.0 \%$ $\mathrm{OM}, 13.6 \% \mathrm{CP}, 27.2 \% \mathrm{NDF}, 10.3 \% \mathrm{ADF}$, and $49.6 \% \mathrm{NFC})$ was fed with silage at a restricted intake of $1 \%$ BW (DM basis). Drinking water and a mineral salt block were available ad libitum. Concentrate was provided before silage and was always consumed completely before feeding the silage. The feeding regime was estimated to exceed maintenance recommendations for $\mathrm{ME}$ and $\mathrm{CP}$ (NRC, 1981) for does weighing $>18 \mathrm{~kg}$. Ingredient and nutrient composition of ingested diets by goats fed silages treated with raw or heated corn is shown in Table 2 .

The experiment lasted for $21 \mathrm{~d}$, with $14 \mathrm{~d}$ for animal adaptation and $7 \mathrm{~d}$ for sample collection. Samples of concentrate, silage, and orts and total feces were collected daily and pooled over the final $7 \mathrm{~d}$ to determine wholetract nutrient digestibility. On d 21, jugular blood samples were taken from each goat at $1100 \mathrm{~h}$. Serum was prepared by centrifugation $\left(3000 \times \mathrm{g}, 20 \mathrm{~min}, 4^{\circ} \mathrm{C}\right)$ and frozen for later analysis. During a pre-trial period, all goats were provided with the control silage plus the same concentrate. The goats did not appear to adapt to the diet, and forage DMI were erratic $(238.7 \pm 83 \mathrm{~g} / \mathrm{d})$.

\section{Laboratory Analyses}

Fresh napiergrass, corn, silage, and fecal samples were determined for DM by incubating samples in a forcedair oven at $55^{\circ} \mathrm{C}$ for $48 \mathrm{~h}$, without adjustment for losses caused by volatilization. The dried samples were ground to pass a $1-\mathrm{mm}$ screen and analyzed for lab $\mathrm{DM}\left(105^{\circ} \mathrm{C}\right.$, $24 \mathrm{~h}$ ). Ash was determined in a muffle furnace at $550^{\circ} \mathrm{C}$ for $8 \mathrm{~h}$. Organic matter was calculated by differences. Ether extract and $\mathrm{CP}$ were determined according to AOAC (1990). The NDF, ADF, and ADL were analyzed by the method of Van Soest et al. (1991). Nonfiber carbohydrate content was calculated by subtracting CP, ether extract, and NDF from OM. Water-soluble carbohydrates of feeds before ensiling and silage samples were extracted by $80 \%$ ethanol and analyzed by colorimetry after reaction to an anthrone reagent (Thomas, 1977). Buffering capacity was measured in milliequivalents of $\mathrm{NaOH}$ required to raise the $\mathrm{pH}$ of $1 \mathrm{~kg}$ of feed $\mathrm{DM}$ from 4.0 to 6.0 (Playne and McDonald, 1966).

For $\mathrm{pH}$ determination, fresh silage $(25 \mathrm{~g})$ was immersed in $100 \mathrm{~mL}$ of distilled water and agitated for 1 $\mathrm{h}$ before measurement using a glass electrode. Fermentation acids were extracted by soaking $25 \mathrm{~g}$ of fresh silage in $0.2 \mathrm{~N} \mathrm{H}_{2} \mathrm{SO}_{4}(200 \mathrm{~mL})$ for $48 \mathrm{~h}$. Lactic acid and VFA in silage were analyzed simultaneously on centrifuged $(10,300 \times g, 30 \mathrm{~min})$ acid extracts by HPLC (ICI Instruments, Victoria, Australia) using an organic column (Interaction Chromatography, San Jose, CA) at $50^{\circ} \mathrm{C}$ and a refractive index detector. The mobile phase was 0.01 $\mathrm{N} \mathrm{H}_{2} \mathrm{SO}_{4}(0.5 \mathrm{~mL} / \mathrm{min})$. Ammonia $\mathrm{N}$ in acid extract was analyzed by the phenol-hypochlorite procedure described by Weatherburn (1967).

Silage digestibility by mixed ruminal microorganisms was measured in vitro. The one-stage incubation (triplicate, $48 \mathrm{~h}$ ) conditions and digestibility determination were similar to those of Goering and Van Soest (1970) as described by Yang (2002). The contents of incubation at termination were also analyzed for VFA and ammonia $\mathrm{N}$ by the methods previously described. Yeast and molds were enumerated, but not differentiated, on pour plates of Sabourand dextrose agar (Difco, Detroit, MI) at $30^{\circ} \mathrm{C}$ for $48 \mathrm{~h}$. Serum samples were analyzed for urea $\mathrm{N}$ and glucose by an automatic instrument (Merck Vitalab Selectra, Merck, Germany).

\section{Statistical Analyses}

Data were subjected to ANOVA by the general linear models procedure of SAS (1998) for a completely randomized design for silage fermentation $(\mathrm{n}=9)$ and animal intake $(n=8)$ experiments, with treatment and residual error included in the model. Data from fungal growth in aerated silages were analyzed by day. Means reported are least squares means. Treatment effect was deter- 
Table 3. Chemical composition, fermentation characteristics, and fungal counts of napiergrass ensiled without (control) and with raw or heated corn meal after 8 wk of ensiling.

\begin{tabular}{|c|c|c|c|c|}
\hline Item $^{1}$ & Control & Raw corn & Heated corn & SEM \\
\hline & & 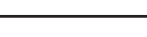 & & $\longrightarrow$ \\
\hline \\
\hline $\mathrm{DM}$ & $15.6^{\mathrm{b}}$ & $17.6^{\mathrm{a}}$ & $17.8^{\mathrm{a}}$ & 0.3 \\
\hline $\mathrm{OM}$ & 89.8 & 90.8 & 91.8 & 0.3 \\
\hline $\mathrm{CP}$ & 8.64 & 8.92 & 8.88 & 0.21 \\
\hline $\mathrm{NDF}$ & $63.8^{\mathrm{a}}$ & $56.0^{\mathrm{b}}$ & $57.6^{\mathrm{b}}$ & 0.5 \\
\hline $\mathrm{ADF}$ & $44.4^{\mathrm{a}}$ & $35.7^{\mathrm{b}}$ & $37.2^{\mathrm{b}}$ & 0.4 \\
\hline Ether extract & 5.32 & 5.24 & 5.44 & 0.17 \\
\hline $\mathrm{ADL}$ & $6.24^{\mathrm{a}}$ & $4.36^{\mathrm{b}}$ & $3.77^{\mathrm{b}}$ & 0.22 \\
\hline $\mathrm{NFC}$ & $12.0^{\mathrm{b}}$ & $20.6^{\mathrm{a}}$ & $19.9^{\mathrm{a}}$ & 0.3 \\
\hline WSC & 0.59 & 0.76 & 0.85 & 0.07 \\
\hline \multicolumn{5}{|l|}{ Silage characteristics } \\
\hline $\mathrm{pH}$ & $4.75^{\mathrm{a}}$ & $4.58^{\mathrm{b}}$ & $4.41^{\mathrm{c}}$ & 0.02 \\
\hline Lactic acid (L), \% of DM & $2.37^{\mathrm{b}}$ & $4.01^{\mathrm{a}}$ & $3.39^{\mathrm{a}}$ & 0.13 \\
\hline Acetic acid (A), \% of DM & $10.10^{\mathrm{a}}$ & $7.08^{b}$ & $7.61^{b}$ & 0.42 \\
\hline Propionic acid, \% of DM & $1.32^{\mathrm{b}}$ & $4.08^{\mathrm{a}}$ & $2.83^{\mathrm{a}}$ & 0.23 \\
\hline Butyric acid, \% of DM & $0.20^{\mathrm{b}}$ & $6.60^{\mathrm{a}}$ & $5.20^{\mathrm{a}}$ & 0.54 \\
\hline $\mathrm{L}: \mathrm{A}$ & $0.25^{\mathrm{b}}$ & $0.56^{\mathrm{a}}$ & $0.42^{\mathrm{a}}$ & 0.04 \\
\hline Ammonia N, \% of $\mathrm{N}$ & 22.4 & 21.7 & 22.5 & 0.2 \\
\hline Fungi, log cfu/g of DM & 5.90 & 5.40 & 5.14 & 0.18 \\
\hline \multicolumn{5}{|c|}{ In vitro ruminal fermentation } \\
\hline DM disappearance, $\%$ & $60.5^{\mathrm{b}}$ & $70.6^{\mathrm{a}}$ & $72.1^{\mathrm{a}}$ & 1.2 \\
\hline NDF disappearance, \% & $58.5^{\mathrm{b}}$ & $66.2^{\mathrm{a}}$ & $69.4^{\mathrm{a}}$ & 1.1 \\
\hline Ammonia N, mg/100 mL & $3.97^{\mathrm{b}}$ & $4.05^{\mathrm{b}}$ & $6.18^{\mathrm{a}}$ & 0.07 \\
\hline $\mathrm{pH}$ & $6.67^{\mathrm{a}}$ & $6.57^{\mathrm{b}}$ & $6.56^{\mathrm{b}}$ & 0.02 \\
\hline Total VFA, mM & $76.7^{\mathrm{b}}$ & $95.8^{\mathrm{a}}$ & $99.6^{\mathrm{a}}$ & 1.5 \\
\hline \multicolumn{5}{|l|}{ VFA, mol/100 mL } \\
\hline Acetic acid (A) & $63.9^{\mathrm{a}}$ & $56.5^{\mathrm{b}}$ & $57.1^{\mathrm{b}}$ & 0.4 \\
\hline Propionic acid (P) & $23.4^{\mathrm{b}}$ & $29.6^{\mathrm{a}}$ & $28.9^{\mathrm{a}}$ & 0.3 \\
\hline Butyric acid & $7.24^{\mathrm{b}}$ & $9.16^{\mathrm{a}}$ & $8.92^{\mathrm{a}}$ & 0.09 \\
\hline Valeric acid & $1.68^{\mathrm{a}}$ & $1.05^{\mathrm{b}}$ & $1.04^{\mathrm{b}}$ & 0.05 \\
\hline BCFA & 3.93 & 3.89 & 4.11 & 0.05 \\
\hline $\mathrm{A}: \mathrm{P}$ & $2.72^{\mathrm{a}}$ & $1.93^{\mathrm{b}}$ & $1.96^{\mathrm{b}}$ & 0.06 \\
\hline
\end{tabular}

a,b,c Means (3 samples for each mean) in rows with unlike superscripts differ $(P<0.05)$.

${ }^{1} \mathrm{ADL}=$ acid detergent lignin, $\mathrm{NFC}=$ nonfiber carbohydrate $(\mathrm{OM}-\mathrm{CP}-$ ether extract $-\mathrm{NDF}), \mathrm{WSC}=$ water-soluble carbohydrates, Fungi = yeasts plus molds; BCFA = branched-chain fatty acids (isobutyric plus isovaleric acids).

mined by an $F$ ratio, with $P<0.05$ being considered significant.

\section{RESULTS}

\section{Silage Composition and Fermentation Characteristics}

Adding corn meals to napiergrass at the time of ensiling increased $(P<0.05)$ silage DM contents over the control silage by $13 \%$ (Table 3). Organic matter, ether extract, $\mathrm{CP}$, and residual WSC did not differ significantly among treatments. The NDF, ADF, and ADL concentrations in silages were diluted $(P<0.05)$ by the addition of corn. In contrast, NFC concentration was elevated $(P$ $<0.05)$ for silages containing added corn.

Silage $\mathrm{pH}$ decreased $(P<0.05)$ in response to corn meal addition to the forage at ensiling, with the lowest $(P<$ $0.05)$ value observed for silage containing heated corn meal. Addition of corn resulted in silages with greater $(P$
$<0.05)$ lactic, propionic, and butyric acid concentrations. However, control silage contained significantly more $(P$ $<0.05$ ) acetic acid than did corn-treated silages. A greater $(P<0.05)$ lactic to acetic acid ratio was observed when corn was added. Upon opening silos, ammonia $\mathrm{N}$ as a percentage of total $\mathrm{N}$ and fungal (yeasts plus molds) counts were not significantly affected by treatments.

In vitro ruminal disappearance of DM and NDF was higher $(P<0.05)$ for corn-treated silages compared with the control treatment. Ammonia $\mathrm{N}$ concentration was higher $(P<0.05)$ for substrate silage containing heated corn than for the other two treatments. The $\mathrm{pH}$ decreased $(P<0.05)$ and total VFA concentrations increased $(P<$ $0.05)$ with silages ensiled with corn. Molar proportions of acetic and valeric acids declined $(P<0.05)$, but the proportions of propionic and butyric acids increased $(P$ $<0.05$ ) for silages ensiled with corn. There were no differences in molar proportions of branched-chain VFA be- 
Table 4. Silage DM, pH, and fungal counts after 24 and $48 \mathrm{~h}$ of exposure to air for napiergrass silage without (control) and with raw or heated corn added at ensiling.

\begin{tabular}{lccll}
\hline Item $^{1}$ & Control & Raw corn & Heated corn & SEM \\
\hline $24 \mathrm{~h}$ & & & & \\
DM, \% & $16.6^{\mathrm{b}}$ & $20.6^{\mathrm{a}}$ & $21.1^{\mathrm{a}}$ & 0.4 \\
$\mathrm{pH}$ & $4.87^{\mathrm{a}}$ & $4.67^{\mathrm{b}}$ & $4.52^{\mathrm{c}}$ & 0.03 \\
Fungi, log cfu/g of DM & 6.92 & 6.72 & 6.38 & 0.24 \\
$48 \mathrm{~h}$ & & & & \\
DM, \% & $17.5^{\mathrm{b}}$ & $22.8^{\mathrm{a}}$ & $22.9^{\mathrm{a}}$ & 0.3 \\
pH & $5.01^{\mathrm{a}}$ & $4.76^{\mathrm{b}}$ & $4.64^{\mathrm{b}}$ & 0.03 \\
Fungi, log cfu/g of DM & $7.79^{\mathrm{a}}$ & $6.37^{\mathrm{b}}$ & $5.86^{\mathrm{b}}$ & 0.28 \\
\hline
\end{tabular}

a,b,c Means in rows with unlike superscripts differ $(P<0.05)$.

${ }^{1}$ Fungi $=$ Yeasts plus molds.

cause of treatments. Incubations with corn-added silages decreased $(P<0.05)$ the acetate to propionate ratio.

\section{Changes in Aerated Silages}

Silage DM was lower $(P<0.05)$ for control silage than for silages with added corn at 24 and $48 \mathrm{~h}$ after exposure to air (Table 4). Control silage had the highest $(P<0.05)$ $\mathrm{pH}$ after aeration for $24 \mathrm{~h}$; it was the lowest $(P<0.05)$ for silage treated with heated corn. At $48 \mathrm{~h}$, there was no difference in $\mathrm{pH}$ between silages containing raw and heated corn, but the $\mathrm{pH}$ of both silages remained lower $(P<0.05)$ than that of control silage. Fungal counts in aerated silages were not significantly affected by treatments after exposure to air for $24 \mathrm{~h}$. However, fewer $(P$ $<0.05$ ) fungal counts were observed for silages with added corn at $48 \mathrm{~h}$.

\section{Silage Intakes}

Actual intake of silage DM or intake as a percentage of BW tended to increase $(P<0.10)$ when napiergrass was ensiled with heated corn vs. raw corn (Table 5). Total feed DMI (silage plus concentrate) also tended to be greater $(P<0.10)$ for does fed the diet containing silage with heated corn. Silage treatments had no significant influence on apparent whole-tract digestibility of DM, $\mathrm{OM}, \mathrm{CP}, \mathrm{NDF}, \mathrm{ADF}$, and NFC. Serum glucose and urea $\mathrm{N}$ concentrations also did not differ between treatments.

\section{DISCUSSION}

Fresh napiergrass harvested in this study had composition values comparable with reference values for the grass at a late stage of growth, with typical high moisture and structural carbohydrates (NRC, 1989). Differences in chemical concentrations between napiergrass and corn are generally reflected in the composition of treatment silages, except for $\mathrm{CP}$, ether extract, NFC, and WSC. The slight reduction in silage $\mathrm{CP}$ relative to that of all
Table 5. Dry matter intake, whole-tract nutrient digestibility, and serum measurements of dairy goats fed napiergrass ensiled with raw or heated corn meal.

\begin{tabular}{lllr}
\hline Item $^{1}$ & Raw corn & Heated corn & SEM \\
\hline DMI, g/d & & & \\
Silage & $352.0^{\mathrm{b}}$ & $407.8^{\mathrm{a}}$ & 12.0 \\
Concentrate & 181.7 & 182.3 & 8.0 \\
Total & $533.7^{\mathrm{b}}$ & $590.2^{\mathrm{a}}$ & 13.5 \\
DMI, \% of BW & & & \\
Silage & $2.01^{\mathrm{b}}$ & $2.18^{\mathrm{a}}$ & 0.04 \\
Concentrate & 1.0 & 1.0 & \\
Total & $3.01^{\mathrm{b}}$ & $3.18^{\mathrm{a}}$ & 0.04 \\
Digestibility, \% & & & \\
DM & 72.5 & 72.1 & 1.4 \\
OM & 73.1 & 72.7 & 1.3 \\
CP & 69.2 & 69.9 & 1.6 \\
NDF & 65.8 & 66.5 & 1.4 \\
ADF & 66.1 & 64.3 & 2.0 \\
NFC & 89.2 & 87.2 & 1.5 \\
Serum & & & \\
Glucose, mg/dL & 48.3 & 51.0 & 0.9 \\
Urea N, mg/dL & 6.77 & 8.67 & 0.8 \\
\hline
\end{tabular}

${ }^{\mathrm{a}, \mathrm{b}}$ Means in rows with unlike superscripts differ $(P<0.10)$.

${ }^{1} \mathrm{NFC}=$ nonfiber carbohydrate $(\mathrm{OM}-\mathrm{CP}-$ ether extract $-\mathrm{NDF})$.

fresh ingredients prior to ensiling could be attributed to ammonia losses from proteolysis during fermentation and subsequent ventilation (Muck, 1988). Concentrations of silage WSC and NFC were also reduced to less than the theoretical estimates, as could be expected from saccharolytic activity by silage microorganisms. On the contrary, silage ether extract contents invariably increased for all silage treatments over those of individual ingredients, presumably because of the formation of short-chain fatty acids. Except for DM, the composition of silages treated with corn generally approximates that of corn silage (NRC, 1989).

Attainment of a low $\mathrm{pH}$ is one of the important determinants for final silage fermentation quality and is implicated with various factors and their interactions. A WSC level of $>10 \%$, a low BC ( $<25$ meq. \%), and a DM content of $>20 \%$ are considered desirable for silage preservation (McDonald et al., 1991). At the time of ensiling, the napiergrass contained inadequate WSC and was high in both $\mathrm{BC}$ and moisture content. Positive responses in $\mathrm{pH}$ reduction and acid production to corn treatment suggest that corn was effective in providing fermentable carbohydrates. Because corn contained negligible amounts of WSC compared with grass, the supplementation would have lowered WSC in mixtures at ensiling. Fermentable carbohydrates in corn during ensiling probably originated from the NFC fraction, presumably starch, other than WSC.

The final $\mathrm{pH}$ of silage fermentation has been reported to correlate negatively with the WSC to $\mathrm{BC}$ ratio (Muck, 1988). Although mono- or disaccharides are the typical substrates for lactic acid bacteria, the hydrolysis of non- 
fiber polysaccharides, such as starch, could also provide hexoses for fermentation. Muck (1988) indicated that the measurement of WSC alone might underestimate substrate availability for lactic bacteria. In the present study, estimated NFC to BC ratios in silage treatment mixtures at ensiling (data not shown) are more related to changes in silage $\mathrm{pH}$ and acid production than the WSC to BC ratios. Silage with heated corn contained less total acids numerically but had a lower $\mathrm{pH}$ than silage with added raw corn. This result could be explained by a lower BC for heated corn. Therefore, fewer fermentation acids would be needed to reduce $\mathrm{pH}$. Overall, the improved fermentation of corn-treated mixtures can be attributed to the higher NFC content and to the lower BC with corn.

Lactic acid is preferred over other silage fermentation acids because it has a lower dissociation constant ( $\mathrm{pKa}=$ 3.86); therefore, it is the major organic acid responsible for decreasing silage $\mathrm{pH}$. A minimum lactic acid concentration of $3 \%$ is thought to be indicative of good quality silage (McDonald et al., 1991). Adding corn increased lactic acid concentration in silage by $40 \%$ (to be $>3 \%$ of $\mathrm{DM}$ ) and reduced $\mathrm{pH}$. A similar magnitude of reduction in acetic acid was observed. A more homolactic fermentation was enhanced when corn was added. However, acetic acid remained the predominating acid in the silages followed by butyric acid. Nevertheless, the efficiency of fermentation, judged by greater lactic to acetic acid ratios, was still improved when corn was included in silages. Yokota et al. (1991) reported the main acid in napiergrass silage to be acetic acid. Our results were consistent with their observations.

Adding WSC sources, such as molasses (Yokota et al., 1991), glucose (Tamada et al., 1999), and cassava meal (Panditharatne et al., 1986), to fresh napiergrass at the time of ensiling has resulted in increased lactic acid production with simultaneous decreases in VFA. Our results showed that adding corn was also effective in elevating lactic acid, but other acids increased as well, except acetic acid. Sibanda et al. (1997) added corn (50 and $100 \mathrm{~g}$ of ground corn $/ \mathrm{kg}$ of fresh weight) to tropical grass containing high amounts of legume at ensiling and observed a decreased silage $\mathrm{pH}$ without increasing lactic acid. Instead, both acetic and butyric acids increased. These results indicate that addition of corn, which contained fermentable carbohydrates in a less readily soluble form, could also promote heterolactic and/or perhaps secondary fermentation.

Clostridial activity is largely responsible for secondary fermentation and is potentially detrimental because of the production of butyric acid and ammonia from degradation of carbohydrates, lactic acid, and AA (McDonald et al., 1991). A butyric acid concentration of $<1 \%$ of silage $\mathrm{DM}$ is considered desirable. High moisture $(>70 \%)$ and moderate $\mathrm{pH}(>4.5)$ generally favor clostridial fermentation (Muck, 1988). When corn was added at ensiling, silage DM did increase appreciably but remained $<30 \%$. The $\mathrm{pH}$ decreased but only to about 4.5. Based on the increased butyric acid to a level $>1 \%$ of $\mathrm{DM}$, it is suspected that clostridial fermentation might have been enhanced by corn supplementation.

Ammonia $\mathrm{N}$ was high for all silages and greater than the acceptable level of $10 \%$ of total N (Church, 1991). Yokota et al. (1991) also reported a high concentration $(>20 \%)$ of ammonia $\mathrm{N}$ in napiergrass silage N. Although elevated butyric acid implies enhanced clostridial fermentation by corn supplementation, ammonia $\mathrm{N}$ content did not increase, probably because of increased availability of fermentable carbohydrates, which might have minimized microbial production of ammonia $\mathrm{N}$.

Fungi are the microorganisms most often associated with aerobic deterioration of silage (Woolford, 1990). Slightly lower fungal counts along with reduced $\mathrm{pH}$ in silages treated with corn are indicative of improved stability during aeration. Among silage acids, lactic acid has been associated with aerobic fungal growth (Weinberg et al., 1993). In contrast, acetic, propionic, and butyric acids are inhibitory, with butyric acid being the most efficacious (Woolford, 1975). In this experiment, the combination of these antifungal acids was $35 \%$ greater as result of corn addition. In particular, propionic acid more than doubled, and butyric acid increased at least 25-fold. The increased lactic acid in corn-treated silage did not cause fungal proliferation. Indeed, there were numerically lower counts with these silages. Higher contents of propionic and butyric acids in corn-treated silages might have contributed to the suppressed fungal populations before and after aeration.

The increased in vitro DM digestibility for silages ensiled with corn over non-treated silage could be expected because of the higher concentration of NFC and lower concentration of NDF. However, NDF digestion was also improved in corn-treated silages, suggesting that the inclusion of corn at ensiling might have made forage NDF more degradable by ruminal microorganisms or in vitro fibrolytic activity might have been enhanced. The shift to more propionate from ruminal fermentation after incubation with corn-treated silages is typical when more readily degradable carbohydrates are present in the rumen (Theurer et al., 1999). Higher ammonia $\mathrm{N}$ for silage treated with heated corn might have been due to greater microbial activity during incubation.

Voluntary DMI by animals is affected by the nutritive quality of forages. Acetic (Rook and Gill, 1990) and butyric acid (Wilkins et al., 1971) concentrations in grass silage were negatively correlated with intake. In this experiment, erratic intakes were observed when does were offered the control silage during a preliminary pe- 
riod. This result might have been related to high acetic acid contents (>8.74\% of DM; Rook and Gill, 1990). On the other hand, does tended to eat more silage treated with heated corn over raw corn, probably a result of numerically lower butyric acid or related to the slightly improved in vitro ruminal digestion.

Feeding heated corn to cattle in replacement of raw corn that constitutes large proportions $(>35 \%)$ of diets has increased digestibility, altered blood metabolites, and improved performance without affecting DMI (Theurer et al., 1999). The proportion of corn from silages in total diets was $<24 \%$ in the present study. Whole-tract nutrient digestibility and serum glucose and ammonia $\mathrm{N}$ were not altered, although does ate more silage treated with heated corn.

\section{CONCLUSIONS}

Napiergrass was high in moisture and structural carbohydrate contents and in $\mathrm{BC}$, but was inadequate in fermentable carbohydrates. Corn supplementation to the grass at a level to mimic minimal grain content in corn silage improved the efficiency of silage fermentation by increasing lactic acid with a reduction in $\mathrm{pH}$. The suppressed fungal numbers with corn-treated silages at 48 $\mathrm{h}$ after aerobic exposure could be attributed to elevated antifungal acids and elevated propionic and butyric acids. Using heated corn appeared superior to raw corn as evidenced by the trend of lower silage $\mathrm{pH}$ and fungal counts during aeration and slightly increased intake by dairy does.

\section{ACKNOWLEDGMENTS}

This study was supported by National Science Council (NSC 89-2313-B-197-013), Taiwan, Republic of China.

\section{REFERENCES}

Association of Official Analytical Chemists. 1990. Official Methods of Analysis. Vol. I. 15th ed. AOAC, Arlington. VA.

Church, D. C. 1991. Livestock Feeds and Feeding. 3rd ed. Prentice Hall, Inc., Englewood, NJ.

Goering, H. K., and P. J. Van Soest. 1970. Forage Fiber Analyses (Apparatus, Reagents, Procedures and Some Applications). Agric. Handbook No. 379. ARS-USDA, Washington, DC.

McDonald, P., A. R. Henderson, and S. J. E. Heron. 1991. The Biochemistry of Silage. 2nd ed. Chalcombe Publ., Bucks, England, UK.

Muck, R. E. 1988. Factors influencing silage quality and their implications for management. J. Dairy Sci. 71:2992-3002.
National Research Council. 1981. Nutrient Requirements of Goats: Angora, Dairy, and Meat Goats in Temperate and Tropical Countries. National Academy Press, Washington, DC.

National Research Council. 1989. Nutrient Requirements of Dairy Cattle. 6th rev. ed. Natl. Acad. Sci., Washington, DC.

Panditharatne, S., V. G. Allen, J. P. Fontenot, and M. C. N. Jayasuriya. 1986. Ensiling characteristics of tropical grasses as influenced by stage of growth, additives, and chopping length. J. Anim. Sci. 63:197-207.

Playne, M. J., and P. McDonald. 1966. The buffering constituents of herbage and of silage. J. Sci. Food Agric. 17:264-268.

Rook, A. J., and M. Gill. 1990. Prediction of the voluntary intake of grass silages by beef cattle. 1. Linear regression analysis. Anim. Prod. 50:425-438.

Ruiz, T. M., W. K. Sanchez, C. R. Staples, and L. E. Sollenberger. 1992. Comparison of 'Mott' dwarf elephantgrass silage and corn silage for lactating dairy cows. J. Dairy Sci. 75:533-543.

SAS User's Guide: Statistics, Version 7 Edition. 1998. SAS Inst., Inc., Cary, NC.

Sibanda, S. R., M. Jingura, and J. H. Topps. 1997. The effect of level of inclusion of the legume Desmodium uncinatum and the use of molasses or ground maize as additives on the chemical composition of grass- and maize-legume silages. Anim. Feed Sci. Technol. 68:295-305.

Tamada, J., H. Yokota, and M. Ohshima. 1999. Effect of additives, storage temperature and regional difference of ensiling on the fermentation quality of napier grass (Pennisetum purpureum Schum.) silage. Asian-Aust. J. Anim. Sci. 12:28-35.

Theurer, C. B., J. T. Huber, A. Delgado-Elorduy, and R. Wanderley. 1999. Invited review: Summary of steam-flaking corn or sorghum grain for lactating dairy cows. J. Dairy Sci. 82:1950-1959.

Thomas, T. A. 1977. An automated procedure for the determination of soluble carbohydrates in herbage. J. Sci. Food Agric. 28:639-642.

Umaña, R., C. R. Staples, D. B. Bates, C. J. Wilcox, and W. C. Mahanna. 1991. Effect of a microbial inoculant and(or) sugarcane molasses on the fermentation, aerobic stability, and digestibility of bermudagrass ensiled at two moisture contents. J. Anim. Sci. 69: 4588-4601.

Van Soest, P. J., J. B. Robertson, and B. A. Lewis. 1991. Methods for dietary fiber, neutral detergent fiber, and nonstarch polysaccharides in relation to animal nutrition. J. Dairy Sci. 74:3583-3597.

Weatherburn, M. W. 1967. Phenol-hypochlorite reaction for determinations of ammonia. Anal. Chem. 39:971-974.

Weinberg, Z. G., G. Ashbell, Y. Hen, and A. Azriell. 1993. The effect of applying lactic acid bacteria at ensiling on the aerobic stability of silage. J. Appl. Bacteriol. 75:512-518.

Whitlock, L. A., T. J. Wistuba, M. K. Seifers, R. V. Pope, and K. K. Bolsen. 2000. Effect of surface-spoiled silage on the nutritive value of corn silage diets. J. Dairy Sci. 83(Suppl. 1):110. (Abstr.)

Wilkins, R. J., K. J. Hutchinson, R. F. Wilson, and C. E. Harris. 1971. The voluntary intake of silage by sheep. I. Interrelationships between silage composition and intake. J. Agric. Sci. (Camb.) 77:531-537.

Woolford, M. K. 1975. Microbiological screening of the straight chain fatty acids $\left(\mathrm{C}_{1}-\mathrm{C}_{12}\right)$ as potential silage additives J. Sci. Food Agric. 26:219-228.

Woolford, M. K. 1990. The detrimental effects of air on silage. J. Appl. Bacteriol. 66:101-116.

Yang, C.-M. J. 2002. Response of forage fiber degradation by ruminal microorganisms to branched-chain volatile fatty acids, amino acids, and dipeptides. J. Dairy Sci. 85:1183-1190.

Yokota, H., T. Okajima, and M. Ohshima. 1991. Effect of environmental temperature and addition of molasses on the quality of napiergrass (Pennisetum purpureum Schum.) silage. Asian-Austral. J. Anim. Sci. 4:377-382. 